Document donwnloaded from:

[http://redivia.gva.es/handle/20.500.11939/5143]

This paper must be cited as:

[Alamar, M.C., Vanstreels, E., Oey, M.L., Moltó, E., Nicolai, B. M. (2008). Micromechanical behaviour of apple tissue in tensile and compression tests: Storage conditions and cultivar effect. Journal of Food Engineering, 86(3), 324-333.]

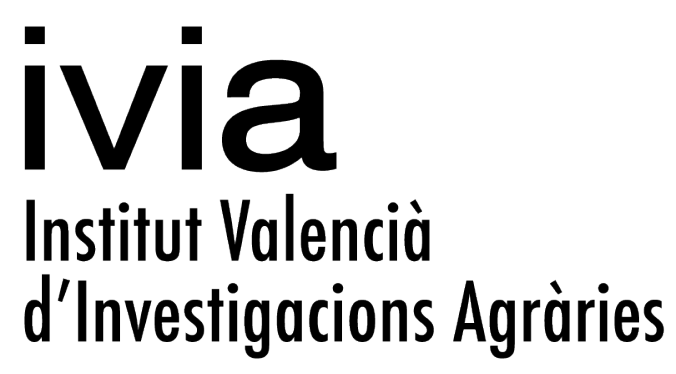

The final publication is available at

[https://doi.org/10.1016/j.jfoodeng.2007.10.012]

Copyright [Elsevier] 


\section{Micromechanical Behaviour of Apple Tissue in Tensile and 2Compression Tests: Storage Conditions and Cultivar Effect}

3

4M.C. Alamar ${ }^{1}$, E. Vanstreels ${ }^{2}$, M.L.Oey ${ }^{3}$, E. Moltó ${ }^{1}$, B.M. Nicolaï ${ }^{2}$

${ }^{1}$ Instituto Valenciano de Investigaciones Agrarias / Centro de Agroingeniería. Ctra. 6Moncada-Náquera, Km.4.5, 46113, Moncada-Valencia, Spain.

$7^{2}$ Rega Institue for Medical Research. Minderbroedersstraat 10, 3000 Leuven, Belgium $8^{3}$ Flanders Centre of Postharvest Technology / BIOSYST-MeBioS, Catholic University of 9Leuven, W. de Croylaan 42, B-3001 Leuven, Belgium

10

11Corresponding author: $\mathrm{M}^{\mathrm{a}}$ Carmen Alamar

12

13Keywords: Malus domestica, texture, firmness, elasticity, storage, histology 


\section{Abstract.}

15The micromechanical behaviour of apple tissue was studied using a miniature tensile 16stage positioned underneath a microscope that allowed for simultaneous acquisition of 17 force-displacement curves while the deformation of the individual cells was followed and 18recorded. Tensile and compression tests were performed on small samples of apple 19parenchyma of two different cultivars (Jonagored and Braeburn) and two storage 20conditions (control and shelf-life). Tests on the repeatability of the methods has provided 21satisfactory results and will allow the reduction of samples in further experiments. Under 22tensile loading, no differences for any of the mechanical parameters were found between 23cultivars, while a significant storage effect was observed for both cultivars. This opens the 24possibility of developing new sensors for quality assessment. Differences were found 25when studying the relationship of mechanical properties at the micro- and macro- level, 26which requires further investigation. The insights gained in this research will be useful 27when developing mathematical models based upon the mechanical behaviour of apple 28tissue. 


\section{Introduction}

30During harvest, transport, storage and packing, fruits are subjected to mechanical loading 31which may cause damage and loss in commercial value. The susceptibility to mechanical 32damage depends on the mechanical properties. Traditionally, in most of the techniques for 33the evaluation of fruit mechanical properties, it is assumed that the fruit behaves as a 34continuum material in which the mechanical properties essentially do not depend on the 35spatial scale. However, fruits consist of different tissues, which in their turn form a 36complex conglomerate of cells. The fleshy part of fruit is parenchyma tissue and is 37composed of three primary components: parenchyma cells, an adhesive middle lamella 38between adjacent cells and intercellular spaces; cell walls provide mechanical strength to 39the whole cell structure. Since macroscopic mechanical behaviour of fruits depends on 40several microscopic properties (cell size, internal turgor pressure, cell wall mechanical 41properties and thickness, etc) (Heredia et al., 1995; Konstankiewicz et al., 2001), a 42micromechanical approach is useful to understand the relative importance of these 43cellular and histological attributes on the overall mechanical behaviour of fruits and 44vegetables.

45A significant amount of studies have been done on the micromechanics of potato tuber 46parenchyma tissue. Hiller and Jeronimidis (1996) assessed the fracture behaviour for two 47different varieties and predicted critical crack lengths (for different turgor states) by 48means of the compressive elasticity modulus and work of fracture. Konstankiewicz et al. 49(2001) concluded that structural parameters like cell area and cell perimeter exert a 50significant influence on mechanical parameters like strength and elasticity modulus. 51Hepworth and Bruce (2000) measured the deformation of individual cell within potato 52living tissue under uniaxial compression load. Cell deformation was successfully related 
53to macroscopic tissue deformation, up to compressive strains of $20 \%$. Onion epidermal 54tissue has been a subject of research as well. Mechanical properties and molecular 55dynamics in single cell walls were studied by Fourier-transform infrared spectroscopy 56under mechanically stressed conditions (Wilson et al., 2000). Recently, the variation in 57 mechanical properties and structural parameters of onion epidermal peels originating 58from different layers has been investigated (Vanstreels et al., 2005).

59Little research has been carried out so far on the micromechanics of fruit tissue. Allende 60et al. (2004) studied the relationship between the histology of tomato skin and its rupture 61strength. Rojas et al (2002) proposed an empirical model to study the relative contribution 62of structural parameters to the rheology of kiwifruit by performing large deformation 63assays. Harker et al. (1997) investigated the cellular basis of textural diversity in different 64fruits (banana, avocado, melon) using tensile measurements of tissue strength and 65determined the mechanisms of tissue failure by low temperature scanning electron 66microscopy. Other studies on fruit focused on the influence of turgor on structural and 67mechanical properties using e.g. pear tissue (De Belie et al., 2000) or apple tissue (Oey et 68al., 2007).

69In the aforementioned experiments, only in very few cases the mechanical behaviour has 70been investigated simultaneously with visual observation of the actual deformations at the 71microstructural level. The objectives of our study were, therefore (i) to study the effect of 72external factors (e.g. acquisition zone) in the measurements, (ii) to compare the 73micromechanical behaviour of apple cultivars stored under different conditions, and (iii) 74to study the relationship of mechanical properties at the micro- (cellular) and macroscopic 75(tissular) level. For this purpose micromechanical experiments were carried out on two 
76different apple cultivars with known differences in structural parameters and differences 77in mechanical properties due to different storage conditions.

\section{Materials and methods}

\subsection{Cultivars and sample preparation}

80The apple cultivars Jonagored and Braeburn were chosen since significant structural 81differences between them have been described (Schotsmans, 2003). Jonagored apples 82have less number of cells $/ \mathrm{mm}^{2}$, more intercellular space (\%) and larger cells than 83Braeburn apples. Fruits were harvested in October 2004 at the experimental station 84PCFruit-PPS in Velm (Belgium). Apples were selected on the basis of uniformity, 85absence of damage or blemishes and size (average diameter between $85-90 \mathrm{~mm}$ for 86Jonagored, and 60-65 $\mathrm{mm}$ for Braeburn). For both cultivars, homogeneous batches of 87similar acoustic firmness index were selected. The acoustic firmness was measured using 88a commercial acoustic firmness tester (AFS, Aweta, Nootdorp, The Netherlands). The 89stiffness index $\left(S=f^{2} m^{2 / 3}\right)$ was calculated based on the resonant frequency $(f)$ of the first 90peak frequency and the mass $(m)$ of the fruit (Abbot et al., 1992), and was equal to 30.3 91and $32.1 \mathrm{~Hz}^{2} \mathrm{~kg}^{2 / 3}$ for Jonagored and Braeburn, respectively. After one month at $0.8^{\circ} \mathrm{C}$ and $921^{\circ} \mathrm{C}$ for Jonagored and Braeburn, respectively, and $65 \% \mathrm{RH}$ for both cultivars, half of the 93apples were taken directly from the cool room for the experiment performance 94("control"); the other half were stored for an additional period of 12 days under simulated 95shelf-life conditions $\left(21^{\circ} \mathrm{C}\right.$ and $65 \% \mathrm{RH}$; "shelf-life") and had after storage an average 96stiffness index of 23.3 and $22.1 \mathrm{~Hz}^{2} \mathrm{~kg}^{2 / 3}$ for Jonagored and Braeburn, respectively. The 97experiment thus consisted of four objects ( 2 cultivars $\times 2$ storage conditions).

98The Magness-Taylor firmness of apples before and after simulated shelf-life exposure 99was measured using a universal testing machine (LRX, Lloyd Instruments Ltd., 
100Hampshire, UK) equipped with a cylindrical plunger of $11 \mathrm{~mm}$ diameter. The probe was 101pressed into the fruit flesh at a penetration speed of $8 \mathrm{~mm} / \mathrm{s}$ over a distance of $8 \mathrm{~mm}$. The 102maximal force was used as firmness estimation and was equal to $75 \mathrm{~N}$ (control) and $62 \mathrm{~N}$ 103(shelf-life) for Jonagored and $85 \mathrm{~N}$ (control) and $64 \mathrm{~N}$ (shelf-life) for Braeburn.

104Apple flesh is mechanically very anisotropic. The cells in the inner part of the cortex are 105more or less oriented in radial columns of cylindrical cells stuck end to end (Khan and 106Vincent, 1990; Abbott and Lu, 1996), so we restricted our experiments to tangentially cut 107rectangular beam specimens where the load was applied parallel to cell columns 108distribution (Figure 1). Both a slicer and parallel razor blades to ensure constant 109dimensions and smooth surfaces were used for sample preparation.

110For every apple, six specimens for tensile tests and six for compression tests were taken 111 from two subsequent slices of apple tissue: three samples were acquired from the first 112slice and second slice, respectively. Since strain rate has been proved to have an influence 113on dynamic failure properties (Bajema et al., 2000), a constant strain rate of $0.05 \mathrm{~min}^{-1}$ for 114both tensile and compression tests was selected for our study. The dimensions of the 115apple specimens were $11 \mathrm{~mm} \times 5 \mathrm{~mm} \times 2 \mathrm{~mm}$ for tensile tests and $3 \mathrm{~mm} \times 11 \mathrm{~mm} \times 5$ $116 \mathrm{~mm}$ samples for compression tests. The deformation rates were $0.5 \mathrm{~mm} / \mathrm{min}$ and $0.2 \mathrm{~mm} /$ $117 \mathrm{~min}$ for tensile and compression tests, respectively, and were selected to keep a constant 118strain rate during the mechanical tests.

\subsection{Determination of Isotonic Point}

120Since turgor pressure of cells in tissue affects their mechanical properties (Lin and Pitt, 1211986; De Belie, et al., 2000; Konstankiewicz and Zdunek, 2001), all the samples from 122every batch were equalised by soaking them overnight in its isotonic mannitol solution at 
$1234^{\circ} \mathrm{C}$. Thus, the possible differences in turgor among apples from the same batch were 124avoided.

125The average isotonic point of every object was determined by measuring relative volume 126and weight changes of cylindrical samples of apple tissue $(12 \mathrm{~mm}$ diameter by $5 \mathrm{~mm}$ 127height) after overnight soaking in one of several concentrations of mannitol (from 0 to 1280.8M). For every mannitol concentration, 10 apple cylinders coming from 10 different 129apples were used. In order to minimize cellular degradation of tissue strength during the 130experiment due to $\mathrm{pH}$ variation, and following the method described by Lin and Pitt, 1311986, the mannitol solutions were buffered with $\mathrm{K}_{2} \mathrm{HPO}_{4}(0.02 \mathrm{M})$ and $\mathrm{KH}_{2} \mathrm{PO}_{4}(0.02 \mathrm{M})$. 132Nine tissue cylinders were cut out the cortex of the green side of each apple and placed 133into each osmotic solution. Parenchyma samples represented approximately $1 \%$ of 134solution volume, ensuring a constant water activity value during soaking. Before and after 135the soaking, both weight and dimensions (diameter and height) of the samples were 136determined with an analytical balance (Sartorious, CP124S, Germany) and a digital 137calliper (Absolute Digimatic, Mitutoyo, UK, Ltd.), respectively. The apple-tissue 138cylinders were carefully blotted with tissue paper to remove excess of water before the 139measurements. Eventually, the isotonic point was calculated by interpolation to zero 140weight or volume change from the curve indicating the weight gain or loss of tissue as a 141function of the mannitol concentration.

\subsection{Micromechanical Tests}

143The mechanical testing was carried out on a miniature tensile stage (Deben Microtest, 144Suffolk, U.K.) which, due to its reduced dimensions $(12 \mathrm{~cm} \times 8 \mathrm{~cm})$, could be mounted 145underneath a stereomicroscope (SMZ1000, Nikon, Japan) equipped with a CCD camera 146(JVC, mod. TK-1360, colour $1 / 2$ " CCD). The whole setup allowed the acquisition of force- 
147displacement curves while the deformation of the individual cells was followed and 148recorded.

149The experiments consisted of performing tensile and compression tests on tangential cut 150rectangular specimens of apple parenchyma as described above. In total 8 control and 8 151shelf-life apples were analysed. For each apple 6 specimens for tensile and 6 specimens 152for compression tests were analysed. The day before the test was performed, the apples 153were removed from the cool room and cut, avoiding the outmost $5 \mathrm{~mm}$ of the fruit where 154the flesh is very heterogeneous. Cell turgor pressure was equalized by soaking the 155samples overnight in an isotonic mannitol solution which was previously determined per 156each apple set.

157Additionally, a staining step was necessary to visualize and quantify cell deformations 158that occur during mechanical testing. Preliminary experiments (data not shown) indicated 159that a staining procedure for a small period of time $(\leq 4 \mathrm{~min}$. $)$ did not affect either the 160mechanical nor structural properties of apple samples. The staining time was selected for 161being the shortest at which good images could be recorded. For both mechanical tests 162every sample was gently stained with methylene blue $(7.5 \mathrm{mg} / 100 \mathrm{~mL}$ mannitol isotonic 163solution) for $3 \mathrm{~min}$. While for compression tests no specific adaptations were needed, for 164tensile tests the lateral edges of the apple beams had to be glued with cyanoacrylate 165adhesive to the two moving grips of the miniature tensile stage (Figure 2). After the glue 166was hardened and during the mechanical test humid air was blown over the samples to 167keep them from drying. Once the slope of the curve was stabilized, two loading and 168unloading cycles upon return to zero stress were carried out. Finally, samples were further 169elongated or compressed until rupture. Strain-stress curves were saved for further 170calculations. 


\subsection{Measurement of cell morphological parameters by image analysis}

171Cell morphological parameters were obtained from both the first image and the image 172 where $80 \%$ of the maximal stress was reached in order to calculate cell strain (\%) (Figure 1733). The studied parameters were: perimeter, area (as cell projected area), aspect (Feret 174width-length ratio), roundness $\left(\right.$ perimeter $^{2} / 4 \times \pi \times$ area $)$, length and width. Length was 175estimated in two different ways: (i) as maximum Feret diameter $\left(\mathrm{L}_{\mathrm{f}}\right)$ when studying 176morphological differences between cultivars and treatments; (ii) from the bounding box 177fitted for every cell(Length_box), where the length of the box pointed in the same 178direction as the mechanical load, when studying cell deformations under compression and 179tensile loading. Width was estimated as minimum Feret diameter $\left(\mathrm{d}_{\mathrm{f}}\right)$. The average value 180of all cells per sample was considered. A list of symbols and abbreviations is given in 181Table 1.

182The original images were digitized by means of a Matlab program (MATLAB version. 6.5, 183The MathWorks, Inc., Natick, Ma, USA) before determining cell structural parameters 184using the Image-Pro Plus 4.5 (Media Cybernetics, Silver Spring, USA) image analysis 185software. The same methodology was used in a previous study (Vanstreels, et al., 2005).

\subsection{Data Analysis}

187Force $(\mathrm{N})$ and deformation $(\mathrm{mm})$ data were converted to stress $(\mathrm{MPa})$ and strain $(\%)$ data. 188The strain was calculated as percentage of deformation after test performance. The stress 189values were obtained as force per unit of surface.

190From the stress-strain curves a number of micromechanical parameters such as elasticity 191modulus in different parts of the stress-strain curve, as described below, stress at failure 192 $\left(\varepsilon_{\max }\right)$ and strain at maximum stress $\left(\sigma_{\max }\right)$ were determined. The strain values when the 
$19380 \%$ of the stress was reached $\left(\sigma_{80 \%}\right)$ and the $80 \%$ of the maximum stress $\left(\varepsilon_{80 \%}\right)$ were also 194calculated.

195A linear mixed model was used to statistically analyze the data:

$196 Y_{i j k m t}=\mu+C_{i}+T_{j}+C T_{i j}+A_{k(i j)}+S_{m(k i j)}+R_{t(m k i j)}$

197where $Y_{i j k m t}$ is a mechanical property for the $i^{\text {th }}$ cultivar $(C), j^{\text {th }}$ treatment $(\mathrm{T}), k^{\text {th }}$ apple 198indicator $(A)$ within 'cultivar' $\times$ 'treatment' combination, $m^{\text {th }}$ apple slice $(\mathrm{S})$ within apple 199and $R$ is the random residual effect. 'Cultivar' and 'treatment' were considered as crossed 200fixed factors and 'apple' and 'slice' as random effects. Shapiro-Wilks tests applied over 201the residues of every variable (SAS, version 7, SAS Institute Inc., Cary, NC, USA) 202confirmed that the variables were normally distributed.

\section{Results}

\subsection{Isotonic point and sampling consistency}

205The isotonic point of control Jonagored apples was -1.35 MPa while for control Braeburn 206apples it was -1.23 $\mathrm{MPa}$. After simulated shelf-life storage there was an increase in 207soluble solids for both cultivars and the isotonic point was -1.56 and $-1.48 \mathrm{MPa}$, 208respectively. The values of isotonic conditions for control Jonagored apples are similar to 209values reported by Quiong et al. (1989) for Empire apples.

210No significant differences $(p<0.01)$ among replicates and slices were found for 211micromechanical or structural parameters for any batch.

\subsection{Micromechanical tests}

213Typical stress-strain curves of apple tissue subjected to tensile and compression tests are 214shown in Figure 4 and mean values of mechanical parameters are shown in Table 2 and 215Table 3. Additionally, a summary of the most relevant results is given in Table 4. 


\section{Compression Tests}

217Compression stress-strain curves for apple samples were sigmoid (Figure 5a, b). The 218elasticity modulus was denoted by $\mathrm{E}_{C 1}$ for the first part of the curve and by $\mathrm{E}_{C 2}$ for higher 219strains, corresponding to $80 \%$ stress, approximately (Figure 4). The cyclic part of all tests 220revealed that, after unloading to zero stress some plastic deformation remained and this 221plastic deformation was more pronounced $(\mathrm{p} \leq 0.05)$ for shelf-life apples $(6.84 \%)$ than 222for control apples (4.63\%).

223The average value of both elasticity moduli was different; $\mathrm{E}_{\mathrm{C} 1}$ was about five times higher 224than $\mathrm{E}_{\mathrm{C} 2}$. Moreover, as expected, for $\mathrm{E}_{\mathrm{C} 1}$ and $\mathrm{E}_{\mathrm{C} 2}$ a significant effect of storage conditions 225(p $\leq 0.001)$ was found: control apples were stiffer than shelf-life apples. However, no 226significant differences between cultivars were observed.

227For maximum strain, statistically significant differences were found between cultivars; 228Jonagored specimens were more compressible $\left(\varepsilon_{\max }=28 \%\right)$ than Braeburn samples 229(24\%), while no storage effect could be observed.

230The maximum stress of control Braeburn $\left(\sigma_{\max }=0.56 \mathrm{MPa}\right)$ apples was larger than that of 231control Jonagored samples $\left(\sigma_{\max }=0.36 \mathrm{MPa}\right)$ for $\alpha=0.05$ (data not shown). After shelf 232life storage, the differences were not statistically significant ( 0.34 vs. $0.15 \mathrm{MPa})$. When 233considering the whole apple, however, control Braeburn apples were harder (MT firmness 234of 85) than control Jonagored apples (MT firmness of 75).

\section{Tensile Tests}

236An almost linear relationship was found between stress and strain values for control 237samples while S-shaped curves were found for shelf-life (Figure 5c,d). 
238As in the case of compression loading, the plastic deformation of shelf-life specimens 239subjected to tensile tests was more pronounced $(\mathrm{p} \leq 0.05)$ than for control samples $(2.73$ $240 \%$ vs. $1.47 \%)$.

241For most control samples, an abrupt decrease in stress when the tissue fails was observed 242while for shelf-life samples the peak reached at maximum stress became broader. Also, 243for some Braeburn shelf-life samples a certain tissue extension before the specimen was 244completely broken was observed ('Shelf-life_2' in Figure 5c).

245When comparing cultivars, no significant differences were found for average values of 246strain at maximum stress; however, control Jonagored specimens were more extensible 247than control Braeburn samples (11.36 vs. $7.23 \%$ ); after shelf life storage, these 248differences disappeared.

249When micromechanical parameters were calculated from stress-train curves we found 250statistically significant differences $(\mathrm{p} \leq 0.001)$ between storage conditions for $\mathrm{E}_{\mathrm{T}}$ (elasticity 251modulus for tensile test); control apples had considerably higher $\mathrm{E}_{\mathrm{T}}(5.02 \mathrm{MPa})$ than 252shelf-life apples (2.10 MPa) (Figure 5). A similar decrease of the elasticity modulus for 253lower turgor pressures was also detected in Granny Smith (Tu et al., 1996) and Jonagored 254apples (Oey et al., 2007).

255Stiffness of Braeburn apples was more affected by shelf life storage conditions during the 256interval studied than stiffness of Jonagored apples, corresponding to a more pronounced 257decrease of the elasticity modulus for the former. Similar to $\boldsymbol{\varepsilon}_{\max }$, no differences between 258cultivars were found in terms of stiffness after shelf-life storage. It seems that since the 259middle lamella is mainly affected during ripening processes, the original mechanical 260differences found for control apple tissue subjected to tensile tests, disappeared after 12 261days storage at $20^{\circ} \mathrm{C}$. 


\subsection{Cell morphological parameters}

263The average cell projected area of Braeburn samples taken from 'zone A' was larger $264\left(32.6 \cdot 10^{3} \mu \mathrm{m}^{2}\right)$ than the average cell projected area of Jonagored specimen $\left(29.1 \cdot 10^{3} \mu \mathrm{m}^{2}\right)$ 265(Table 5). For $L_{f}, d_{f}$ and perimeter the same trend was found. However, no significant 266differences were found between cultivars for samples taken from 'zone B.'

267According to cell shape related parameters (i.e., aspect and roundness), no statistically 268significant differences $(\alpha=0.05)$ between cultivars were found. Therefore, in Table 6 the 269values were pooled over cultivar. In this same table, an effect of sampling zone is 270observed between control and shelf-life specimens but no differences were found between 271storage conditions when samples were taken from zone B. The cells from samples 272extracted from zone A that were stored under shelf life conditions were more round (1.12 273and 1.30 for roundness and aspect, respectively) than cells from control apples (1.16 and 2741.38).

275Apples subjected to tensile tests had lower cell deformations (about 6\%) than those under 276compression loading (about 10\%) (Table 7).

\section{Discussion}

\subsection{Sampling consistency}

279Since there were no significant differences among replicates and slices for 280micromechanical or structural parameters, we can assume that sample acquisition and 281manipulation were carried out in a repeatable way and had no influence on the 282observations. Therefore, in future experiments the number of samples taken from the 283same apple can be reduced such that more apples can be included in the study to better 284assess biological variation. 


\subsection{Micromechanical tests}

\section{Compression tests}

287The sigmoid shape found for specimen subjected to compression loading may be 288explained by the microstructure of the tissue. For small strains the elasticity modulus was 289relatively small, this may be due to cell reorganization and compression of the 290intercellular space in response to compression loading. From the recorded images it was 291observed that while initially cells suffered almost no deformation, from a certain point 292cell deformation became more and more clearly. Moreover, since the boundary cells of 293the apple specimen were cut during sample extraction, some fluid would be expelled at 294the beginning of the test. This was also observed by Drazeta et al. (2004). For larger 295strains, the elasticity modulus increased, probably reflecting cell pressurization.

296It is known that tissue failure under compression loading generally occurs due to cell wall 297rupture because of extreme stresses during test performance (De Belie et al., 2000; Diehl 298et al., 1980) and that after shelf life storage, degradation processes of the cell wall start. 299The major changes are related to pectins which are present in both the amorphous matrix 300where the cellulose microfibrils of the primary cell wall are embedded, and the middle 301lamella (Kunzek et al., 1999). For samples subjected to compression tests, the former 302 factor will have a foremost influence on tissue failure. Therefore, since tissue rupture 303mainly depends on the resistance that the cell wall exerts to compression loading, it seems 304logical that control specimen had higher values of maximum stress than shelf-life apples. 305This corresponded with the mechanical parameters obtained from the stress-strain curves. 306Higher strain values for Jonagored apples might be explained on the basis of the structural 307characteristics of apple tissue. Since Jonagored apples have more intercellular spaces than 308Braeburn apples, the former would be more susceptible to compression than Braeburn. 
309For shelf-life apples, ripening and senescence processes which include water loss, 310degradation of pectin substances, etc. might reduce the differences in the mechanical 311properties between cultivars that have been found between control apples.

\section{Tensile tests}

313Stress-strain curves obtained from apple tissue subjected to tensile loading were 314compared with those obtained from other vegetative tissues like Aristolochia brasiliensis 315(Köhler, 2000) or onion epidermis (Wilson et al., 2000; Vanstreels et al., 2004). The clear 316and typical biphasic behaviour observed in the latter was not observed in this research. 317Such behaviour was explained by these authors in terms of cell wall composition where 318fibrils of cellulose are embedded in flexible pectin. Two processes were assumed to be 319involved: reorientation of microfibrils and slip of microfibrils past each other due to 320yielding of the pectin matrix. In apple parenchyma, the intercellular spaces represent an 321 important part of the total volume. Also, apple parenchyma tissue consists of many cell 322layers in which different cells undergo different stresses, which would lead to different 323shape curves.

324As we found in apples, smooth peaks at failure in force-displacement curves were also 325observed for fruits such as muskmelon and banana (Harker et al., 1997b), and pears (De 326Belie et al.,2000). Pectin, which acts as a cementing substance in the middle lamella, 327starts its solubilisation reducing the adhesion between cells during ripening. Tissue failure 328for shelf-life apples would start where the middle lamella was weaker and from that point 329on the apple parenchyma specimen would finally break as a sequential failure of cells 330groups.

331Unlike compression tests, tissue failure under tensile loading involves cell wall tearing 332and/or cell-to-cell debounding. These different ways of rupture would be related to fruit 
333aging. Thus, cells of control apples would break due to tearing of the cell wall while 334failure of ripened apple tissue would occur due to a breakdown of the inter-lamellar 335region (Harker et al., 1997a; Tu et al., 2000). Therefore, since middle lamella is 336considered a weaker material, less applied force is needed to break shelf-life samples than 337control samples under tensile loading.

339Contrary to Schotsmans (2003) we found that Braeburn cells were larger than Jonagored 340cells, what may be attributed to different maturity levels of both apple cultivars in this 341experiment. On the other hand, the values of the aspect ratio of cells of control apples 342were in agreement with values found for Braeburn apples by Drazeta et al. (2004) and for 343other cultivars (Khan and Vincent, 1990).

344From the morphological results, it appears that both sampling zones are different. In 345principle, cells should be similar for specimen extracted from both zones, however, the 346 fact that the samples were not exactly taken from the very same part of the apple might 347explained these differences. Despite the sample acquisition procedure was designed such 348that similar specimens could be obtained (equatorial and tangentially orientated beams) 349 for tensile and compression test performance, it seems that beams extracted from zone B 350were closer to the bottom of the fruit, resulting in smaller cells.

351Related to cell deformations, apple specimens (tissue level) were deformed positively or 352negatively as they were elongated or compressed. Through the recorded images it was 353observed that most of the cells subjected to compression loading undergo negative 354deformations and cells subjected to tensile tests undergo positive deformations. Some 355cells, however, underwent positive deformations under compression loading and negative 
356deformations when the tissue was subjected to tensile tests. This is probably caused by the 357lack of information about the deformations in the third dimension (cell depth).

358 Relationship between mechanical properties at micro- (cellular) and macro359(tissular) level

360Differences were found when studying the relationship of mechanical properties at the 361micro- and macroscopic level. Hence, although control Braeburn apples were harder (had 362higher MT firmness index) than control Jonagored apples, they showed lower $\sigma_{\max }$ than 363Jonagored. This should be further investigated and interpreted in terms of the structural 364parameters of apple parenchyma.

3650 the other hand, samples subjected to compression tests reached significant higher 366values of $\varepsilon \_80 \%$ than samples under tensile loading $(21.47 \%$ vs.7.52\%) (Table 3$)$. 367However, no significant differences of cell deformation values between the two tests were 368found at the cellular level.

369It has to be considered that, when studying deformations at tissue level, deformation of air 370spaces represents an important portion of total volume. Moreover, due to the experimental 371design of the compression tests, the specimen was not completely confined (the upper and 372lower surfaces were not) and at the beginning of the tests there were a certain 373displacement of the grips; they may have slightly distort the measurements. These facts 374might explain the high strain values obtained for compression tests when comparing to 375tensile tests and also that the differences found at tissular level were not found at cellular 376level.

\section{Conclusions}

378The experiments have shown that sample acquisition and manipulation was conducted 379consistently and had no influence on the measurements. This can reduce the amount of 
380samples taken from each apple and will allow focusing on the study of biological 381variation in further experiments.

382Under tensile loading, we found no differences between the two cultivars employed. 383However, they had been selected because they had significant structural differences 384according to number of cells $/ \mathrm{mm}^{2}$, intercellular space (\%) and cell size. Nevertheless, a 385significant effect of storage conditions was found through this micromechanical approach. 386This fact may lead to the development of sensors capable of to infer the senesce stage of 387apples, which can be a useful means to assess apple quality.

388When comparing tests at different scales different trends have been found. For instance, 389the apparently harder apples (with higher MT index, which is a macro test) have shown 390lower $\sigma_{\max }$ during compression tests. Moreover, when comparing cellular deformations 391(microscale) against observed strain values of tissues (macroscale), major differences 392between tensile and compression tests were found in the former than in the later. This 393may have been caused by the influence of the distribution and quantity of intercellular 394spaces and also because of the lack of 3-dimensinal information. These facts highlight the 395importance of the scale in the results and open the way for further research on the 396comprehension of textural properties of apple fruit.

397Eventually, the insights gained from this research will prove valuable when developing 398mathematical models based upon the histological properties of apple tissues to predict 399strain and failure of fruit tissue as a consequence of static loading and impact.

\section{Acknowledgments}

401The authors would like to acknowledge the Consellería d'Agricultura, Pesca i 402Alimentació (Generalitat Valenciana), the Fund for Scientific Research Flanders (F.W.O. 403Vlaanderen), project G.0200.02 and the European Union (Training Site Marie Curie 
404Grant to M.C. Alamar Gavidia, project G056). We also thank the European Science 405Foundation for a Short Term Scientific Mission grant to M.C. Alamar Gavidia (COST 406Action 924, reference code COST-STSM-924-00788).

\section{References}

408Abbott, J.A. \& Lu R. (1996). Anisotropic mechanical properties of apples. Transactions 409 of the ASAE, 39(4): 1451-1459.

410Alamar, M.C., Zarzo, M., Suay, R., Moltó, E., Vanstreels, E., Verlinden, B.E., Nicolai, 411 B.M., Loodts, J., Tijkenes, E. \& Ramon, H. (2005). Micromechanical behaviour of 412 apple tissue in tensile and compression tests. In proceedings of FRUTIC05, 413 Information and technology for sustainable fruit and vegetable production, 414 Montpellier, France.

415Allende, A., Desmet, M., Vanstreels, E., Verlinden, B.E. \& Nicolaï, B.M. (2004). 416 Micromechanical and geometrical properties of tomato skin related to differences in 417 puncture injury susceptibility. Postharvest Biology and Technology, 34, 131-141.

418Bajema, R.W., Baritelle, A.L., Hyde, G.M. \& Pitts, M.J. (2000). Factors influencing 419 dynamic mechanical properties of red "Delicious" apple tissue. Transactions of the 420 ASAE, 43(6), 1725-1731.

421De Belie, N., Hallett, I.C., Harker, F.R. \& De Baerdemaeker, J. (2000). Influence of 422 ripening and turgor on the tensile properties of pears: a microscopic study of cellular 423 and tissue changes. Journal of American Society for Horticultural Science, 125(3), $424 \quad 350-356$.

425Diehl, K.C., Hamann, D.D. \& Whitfield, J.K. (1980). Structural failure in selected raw 426 fruits and vegetables. Journal of Texture Studies, 10 (4): 371-400. 
427Drazeta, L., Lang, A., Hall, A.J., Volz, R.K. \& Jameson, P.E. (2004). Air volume of 428 "Braeburn" apple fruit. Journal of Experimental Botany, 55 (399): 1061-1069.

429Harker, F.R., Redgvell, R.J., Hallet, S.H., Murray, S.H. \& Carter, G. (1997a). Texture of 430 fresh fruit. Hort. Rev., 20:121-224.

431Harker, F.R., Margaret, Stec, M.G.H., Hallet, I.C. \& Bennet, C.L. (1997b). Texture of 432 parenchymatous plant tissue: a comparison between tensile and other instrumental and 433 sensory measurements of tissue strength and juiciness. Postharvest Biology and 434 Technology, 11:63-72.

435Hepworth, D.G. \& Bruce, D.M. (2000). Measuring the deformation of cells within a piece 436 of compressed potato tuber tissue. Annals of Botany Company, 86, 287-292.

437Heredia, A., Jiménez, A. \& Guillén, R. (1995). Composition of plant cell walls. Review. $438 \quad$ Z. Lebensm Unters Forch, 200: 24-31.

439Hiller, S. \& Jeronimidis, S. (1996). Fracture in potato tuber parenchyma. Journal of $440 \quad$ Materials Science, 31, 2779-2796.

441Khan,A.A. \& Vincent, J.F.V. (1990). Anisotropy of apple parenchyma. Journal of the 442 Science of the Food and Agriculture, 52, 455-466.

443Köhler, L. (2000). Biphasic mechanical behaviour of plant tissues. Materials Science and 444 Engineering, 11, 51-56.

445Konstankiewicz, K., Pawlack, K. \& Zduneck, A. (2001). Influence of structural 446 parameters of potato tuber cells on their mechanical properties. Institute of 447 Agrophysics, 15, 243-246.

448Konstankiewicz, K. \& Zdunek, A. (2001). Influence of turgor and cell size on the 449 cracking of potato tissue. Institute of Agrophysics, 15, 27-30. 
450Lin Ta-Te \& Pitt, R.E. (1986). Rheology of apple and potato tissue as affected by cell 451 turgor pressure. Journal of Texture Studies, 17, 291-313.

452Oey, M.L., Vanstreels E., De Baerdemaeker J., Tijskens E., Ramon H., Hertog 453 M.L.A.T.M. \& Nicolaï B. (2007). Effect of turgor on micromechanical and structural 454 properties of apple tissue: A quantitative analysis. Postharvest Biology and 455 Technology, doi:10.1016/j.postharvbio.2006.12.015.

456Qiong, G., Pitt, R.E. \& Bartsch, J.A. (1989). Elastic-plastic constitutive relations of the 457 cell walls of apple and potato parenchyma. Journal of Rheology, 33(2), 233-256.

458Rojas, A.M., Delbon, M., Marangoni, A.G. \& Gersshenson, L.N. (2002). Contribution of 459 cellular structure to the large and small deformation rheological behaviour of 460 kiwifruit. Journal of Food Science, 67(6), 2143-2148.

461Schotsmans, W. (2003). Diffusion properties of pome fruit in relation to storage potential. 462 PhD dissertation, Katholieke Universiteit Leuven, Belgium.

463Tu, K., De Baerdemaeker, J., Deltour, R. \& de Barsy, T. (1996). Monitoring post-harvest 464 quality of Granny Smith apple under simulated shelf-life conditions: destructive, non465 destructive and analytical measurements. International Journal of Food Science and 466 Technology, 31, 267-276.

467Tu, K., Nicolaï, B. \& De Baerdemaeker, J. (2000). Effects of relative humidity on apple 468 quality under simulated shelf temperature storage. Scientia Horticulturae, 85, $217-$ 469229.

470Vanstreels, E., Alamar, M.C., Verlinden, B.E., Enninghorst, A., Loodts, J.K.A., Tijskens, 471 E., Ramon, H. \& Nicolaï, B. M. (2005). Micromechanical behaviour of onion 472 epidermal tissue. Postharvest Biology and Technology, 37, 163-173. 
473Wilson, R.H., Smith, A.C., Kacuráková, M. \& Saunders, P.K. (2000). The mechanical 474 properties and molecular dynamics of plant cell wall polysaccharides studied by 475 Fourier-Transform infrared spectroscopy. Plant Physiology, 124, 297-405. 


\section{Tables}

477Table 1. List of abbreviations and symbols

478

\section{Symbol or Description}

abbreviation

\section{Mechanical parameters}

$\mathrm{E}_{\mathrm{C} 1}$

elasticity modulus of samples under compression tests obtained

from the first part of stress-strain curve

$\mathrm{E}_{\mathrm{C} 2}$

elasticity modulus of samples under compression tests

corresponding to $80 \%$ stress

$\mathrm{E}_{\mathrm{T}} \quad$ elasticity modulus of samples under tensile tests

$\varepsilon_{\max } \quad$ strain at maximum stress

$\sigma_{\max } \quad$ stress at failure

\section{Morphological parameters}

Length_box length of the imaginary surrounding box of a cell whose major axis is in the same direction as the applied mechanical load. This parameter is used for the cell deformation study.

$\mathrm{L}_{\mathrm{f}} \quad$ maximum Feret diameter

$\mathrm{d}_{\mathrm{f}} \quad$ minimum Feret diameter

479

480

481

482 
483Table 2. Mean values \pm standard error of micromechanical parameters for apple tissue subjected to compression loading. For cultivar, the 484values are pooled over storage treatment while when comparing storage effect the data are pooled over cultivar. Values of $\mathrm{p}$ smaller than 4850.05 indicate a significant difference at the $95 \%$ confidence level.

486

\begin{tabular}{|c|c|c|c|c|c|c|}
\hline & \multicolumn{3}{|c|}{ Cultivar } & \multicolumn{3}{|c|}{ Storage conditions } \\
\hline & Braeburn & Jonagored & p-value & Control & Shelf-life & $\mathrm{p}$-value \\
\hline$\sigma_{\max }(\mathrm{Mpa})$ & $0.25 \pm 0.04$ & $0.40 \pm 0.03$ & 0.0121 & $0.47 \pm 0.04$ & $0.21 \pm 0.03$ & 0.0018 \\
\hline $\boldsymbol{\varepsilon}_{\max }(\%)$ & $23.76 \pm 1.32$ & $28.26 \pm 1.23$ & 0.0299 & $28.13 \pm 1.32$ & $24.49 \pm 1.23$ & 0.2242 \\
\hline $\mathrm{E}_{\mathrm{Cl}}(\mathrm{MPa})$ & $0.35 \pm 0.04$ & $0.42 \pm 0.04$ & 0.2556 & $0.54 \pm 0.04$ & $0.26 \pm 0.04$ & 0.0013 \\
\hline $\mathrm{E}_{\mathrm{C} 2}(\mathrm{MPa})$ & $1.72 \pm 0.14$ & $2.01 \pm 0.13$ & 0.1019 & $2.35 \pm 0.14$ & $1.48 \pm 0.13$ & 0.0027 \\
\hline Plastic def. (\%) & $6.57 \pm 0.38$ & $4.90 \pm 0.40$ & 0.2214 & $4.63 \pm 0.38$ & $6.84 \pm 0.41$ & 0.0082 \\
\hline
\end{tabular}

$48 \overline{7}$

488 
489Table 3. Mean values \pm standard error of micromechanical parameters for apple tissue under tensile loading. For cultivar and storage 490conditions data are pooled over storage conditions and cultivar, respectively. P-values are also given.

491

\begin{tabular}{|c|c|c|c|c|c|c|}
\hline & \multicolumn{3}{|c|}{ Cultivar } & \multicolumn{3}{|c|}{ Storage conditions } \\
\hline & Braeburn & Jonagored & p-value & Control & Shelf-life & p-value \\
\hline$\sigma_{\max }(\mathrm{Mpa})$ & $0.22 \pm 0.02$ & $0.24 \pm 0.02$ & 0.1909 & $0.34 \pm 0.02$ & $0.11 \pm 0.02$ & $<0.0001$ \\
\hline$\varepsilon_{\max }(\%)$ & $7.83 \pm 0.72$ & $10.21 \pm 0.66$ & 0.0782 & $9.22 \pm 0.72$ & $8.93 \pm 0.66$ & 0.7398 \\
\hline $\mathrm{E}_{\mathrm{T}}(\mathrm{MPa})$ & $3.91 \pm 0.17$ & $3.19 \pm 0.16$ & 0.1491 & $5.02 \pm 0.17$ & $2.10 \pm 0.16$ & $<0.0001$ \\
\hline Plastic def. (\%) & $1.69 \pm 0.12$ & $2.52 \pm 0.11$ & 0.0595 & $1.47 \pm 0.12$ & $2.73 \pm 0.11$ & 0.0164 \\
\hline
\end{tabular}

492 
493Table 4. This table summaries the results obtained under compression and tensile tests for 494the main mechanical parameters under study. The $>$ symbol is used to indicate that a 495certain parameter (on the left column) reaches a higher value for the experimental factor 496shown in that column.

497

\begin{tabular}{|c|c|c|c|}
\hline Parameters & Test type & Between cultivars & $\begin{array}{l}\text { Between storage } \\
\text { conditions }\end{array}$ \\
\hline \multicolumn{4}{|c|}{ Differences found for compression tests } \\
\hline Curve form & $\mathrm{C}$ & $\begin{array}{l}\text { No difference } \\
\text { (Sigmoid) }\end{array}$ & $\begin{array}{l}\text { No difference } \\
\text { (Sigmoid) }\end{array}$ \\
\hline$\sigma_{\max }$ & $\mathrm{C}$ & Jonagored $>$ Braeburn & Control $>$ Shelf-life \\
\hline $\boldsymbol{\varepsilon}_{\max }$ & $\mathrm{C}$ & Jonagored $>$ Braeburn & No difference \\
\hline $\mathrm{E}_{2}$ & $\mathrm{C}$ & No difference & Control $>$ Shelf-life \\
\hline Plastic deformation & $\mathrm{C}$ & No difference & Shelf-life $>$ Control \\
\hline MT & $\mathrm{C}$ & Braeburn $>$ Jonagored & N.D.* \\
\hline \multicolumn{4}{|c|}{ Differences found for tensile tests } \\
\hline Curve form & $\mathrm{T}$ & No difference & $\begin{array}{l}\text { Linear for control } \\
\text { Sigmoid for shelf-life }\end{array}$ \\
\hline$\sigma_{\max }$ & $\mathrm{T}$ & No difference & Control $>$ Shelf-life \\
\hline $\boldsymbol{\varepsilon}_{\max }$ & $\mathrm{T}$ & No difference & No difference \\
\hline $\mathrm{E}_{2}$ & $\mathrm{~T}$ & No difference & Control $>$ Shelf-life \\
\hline Plastic deformation & $\mathrm{T}$ & No difference & Shelf-life $>$ Control \\
\hline
\end{tabular}

498

499*not determined

500 
501Table 5. Mean values \pm standard error of initial cell size related parameters for apple tissue. For cultivar the values are pooled over storage 502treatment while when comparing storage effect the data are pooled over cultivar. Values of p smaller than 0.05 indicate a significant 503difference at the $95 \%$ confidence level.

\begin{tabular}{|c|c|c|c|c|c|c|c|}
\hline & \multirow[b]{2}{*}{ Zone } & \multicolumn{3}{|c|}{ Cultivar } & \multicolumn{3}{|c|}{ Storage conditions } \\
\hline & & Braeburn & Jonagored & p-value & Control & Shelf-life & p-value \\
\hline \multirow[t]{2}{*}{ Area $\left(\mu \mathrm{m}^{2}\right)$} & A & $32597 \pm 536$ & $29095 \pm 497$ & 0.0190 & $31771 \pm 536$ & $29788 \pm 497$ & 0.1207 \\
\hline & $\mathrm{B}$ & $24730 \pm 568$ & $23920 \pm 526$ & 0.3431 & $21896 \pm 656$ & $26471 \pm 622$ & 0.0035 \\
\hline \multirow[t]{2}{*}{$\mathrm{L}_{\mathrm{f}}(\mu \mathrm{m})$} & A & $237.52 \pm 1.75$ & $223.90 \pm 1.59$ & 0.0153 & $239.00 \pm 1.75$ & $222.62 \pm 1.59$ & 0.0042 \\
\hline & $\mathrm{B}$ & $206.53 \pm 1.66$ & $199.90 \pm 1.53$ & 0.2612 & $193.00 \pm 1.91$ & $212.01 \pm 1.81$ & 0.0119 \\
\hline \multirow[t]{2}{*}{$d_{f}(\mu \mathrm{m})$} & A & $180.0 \pm 1.18$ & $171.86 \pm 1.09$ & 0.0402 & $177.21 \pm 1.18$ & $174.29 \pm 1.09$ & 0.3886 \\
\hline & $\mathrm{B}$ & $154.75 \pm 1.50$ & $156.09 \pm 1.51$ & 0.9938 & $148.43 \pm 1.88$ & $161.78 \pm 1.78$ & 0.0057 \\
\hline \multirow[t]{2}{*}{ Perimeter $(\mu \mathrm{m})$} & A & $663.12 \pm 5.57$ & $628.14 \pm 5.16$ & 0.0252 & $661.27 \pm 5.57$ & $629.73 \pm 5.16$ & 0.0298 \\
\hline & $\mathrm{B}$ & $573.60 \pm 5.99$ & $563.04 \pm 5.55$ & 0.3600 & $540.91 \pm 6.92$ & $592.46 \pm 6.57$ & 0.0068 \\
\hline
\end{tabular}

$50 \overline{4}$

505 
506Table 6. Mean values \pm standard error of initial cell shape related parameters of control 507and shelf-life apple tissue. Values were pooled over cultivar. p-values $<0.05$ indicate a 508significant difference at the $95 \%$ confidence level.

509

\begin{tabular}{lllll}
\hline & & \multicolumn{3}{c}{ Storage conditions } \\
\hline & Zone* & Control & Shelf-life & p-value \\
\hline Aspect & A & $1.38 \pm 0.02$ & $1.30 \pm 0.02$ & 0.0005 \\
& B & $1.32 \pm 0.01$ & $1.33 \pm 0.01$ & 0.6845 \\
Roundness & A & $1.16 \pm 0.01$ & $1.12 \pm 0.01$ & 0.0003 \\
& B & $1.14 \pm 0.01$ & $1.11 \pm 0.01$ & 0.0890 \\
\hline
\end{tabular}

510

511 
512Table 7. Mean values of cell deformation (\%) (judging from length_box deformations) 513and tissue deformation (judging from $\varepsilon_{80} \%$ ), for apple parenchyma under tensile and 514compression loading. \pm Standard deviation is given next to each value.

515

\begin{tabular}{lll}
\hline Test & Compression & Tensile \\
\hline Macroscale & $21.47 \pm 3.55$ & $7.57 \pm 1.65$ \\
Microscale & $9.63 \pm 5.58$ & $6.46 \pm 1.57$ \\
\hline
\end{tabular}

516

517 


\section{Figure captions}

519Figure 1. a) Diagram showing how tangential beam specimens were extracted from an 520apple. The grey bars represent the slices where the samples were extracted from. 521Specimens for compression test were obtained from 'Zone A' while specimens for tensile 522tests were obtained from 'Zone B'. Dimensions of the specimens subjected to 523compression (b) and tensile (c) tests are also shown. The arrows represent the direction of 524the applied load. In $\mathbf{b}$ and $\mathbf{c}$, the mark over the beams indicates the place from where cell 525deformations were observed and recorded.

526Figure 2. Miniature tensile stage (left) with the grips used for compression tests. Close up 527of how the apple specimens for tensile tests were glued to the grips of the bench (right).

528Figure 3. Original images of Jonagored apple tissue as seen through the stereomicroscope. 529(Left) Image obtained at the beginning of the compression test. (Right) Image obtained at $53080 \%$ stress of the compression test. The same cells are denoted with $\mathbf{a}, \mathbf{b}$ and $\mathbf{c}$ so 531differences in their dimensions can be appreciated.

532Figure 4. Representative stress-strain curves of control apple tissue subjected to 533compression (a) and tension (b) loading. The bold lines on the curves represent the region 534from where the elasticity modulus and the associated images were extracted. $E_{C l}$ : elasticity 535 modulus of samples under compression loading obtained at the beginning of the test; $E_{C 2}$ : 536elasticity modulus of samples under compression tests, corresponding to $80 \%$ stress; $E_{T}$ : 537Elasticity modulus of samples under tensile tests; $\sigma_{\max }$ : maximum stress; $\varepsilon_{\max }$ : strain at 538maximum stress.

539Figure 5. Typical stress-strain curves for Braeburn and Jonagored apple tissue under 540different storage conditions (control and shelf-life) subjected to tensile and compression 541tests. 


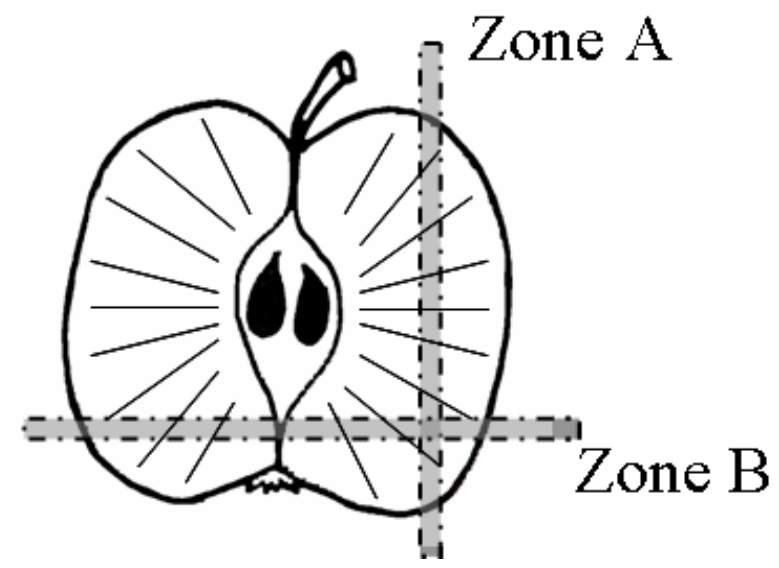

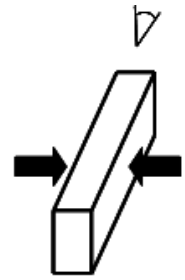

$3 \times 11 \times 5 \mathrm{~mm}$

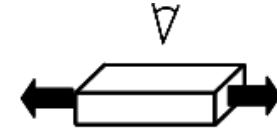

$11 \times 5 \times 2 \mathrm{~mm}$

543

b

c

544Figure 1. a) Diagram showing how tangential beam specimens were extracted from 545an apple. The grey bars represent the slices where the samples were extracted from. 546Specimens for compression test were obtained from 'Zone $A$ ' while specimens for 547tensile tests were obtained from 'Zone B'. Dimensions of the specimens subjected to 548compression (b) and tensile (c) tests are also shown. The arrows represent the 549direction of the applied load. In b and c, the mark over the beams indicates the place 550 from where cell deformations were observed and recorded. 
552
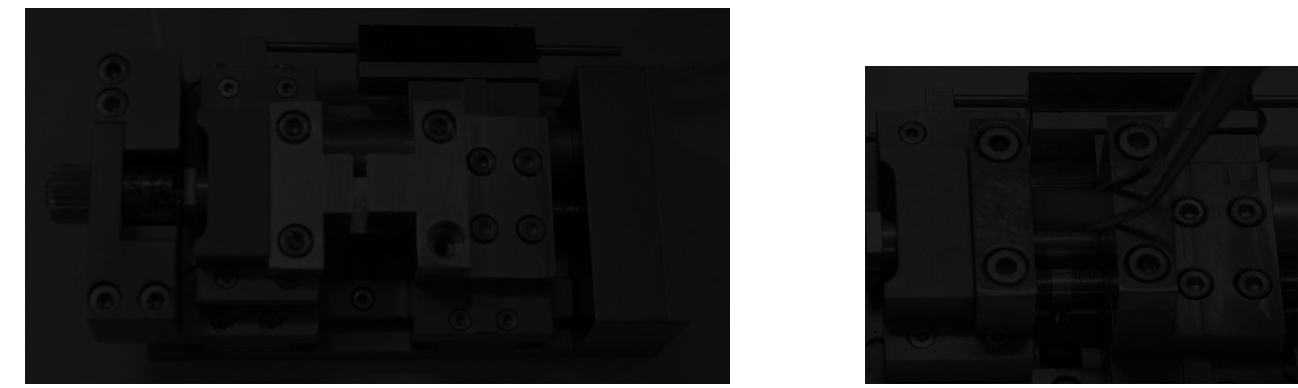

553Figure 2. Miniature tensile stage (left) with the grips used for compression tests. Close up 554of how the apple specimens for tensile tests were glued to the grips of the bench (right). 555 

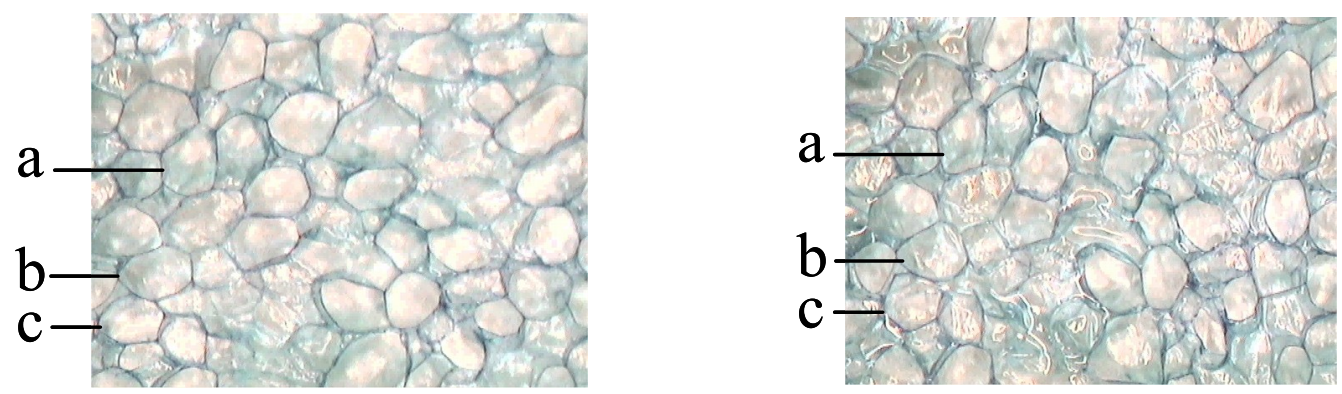

557

558Figure 3. Original images of Jonagored apple tissue as seen through the stereomicroscope. 559(Left) Image obtained at the beginning of the compression test. (Right) Image obtained at $56080 \%$ stress of the compression test. The same cells are denoted with a, b and c so 561differences in their dimensions can be appreciated.

562 


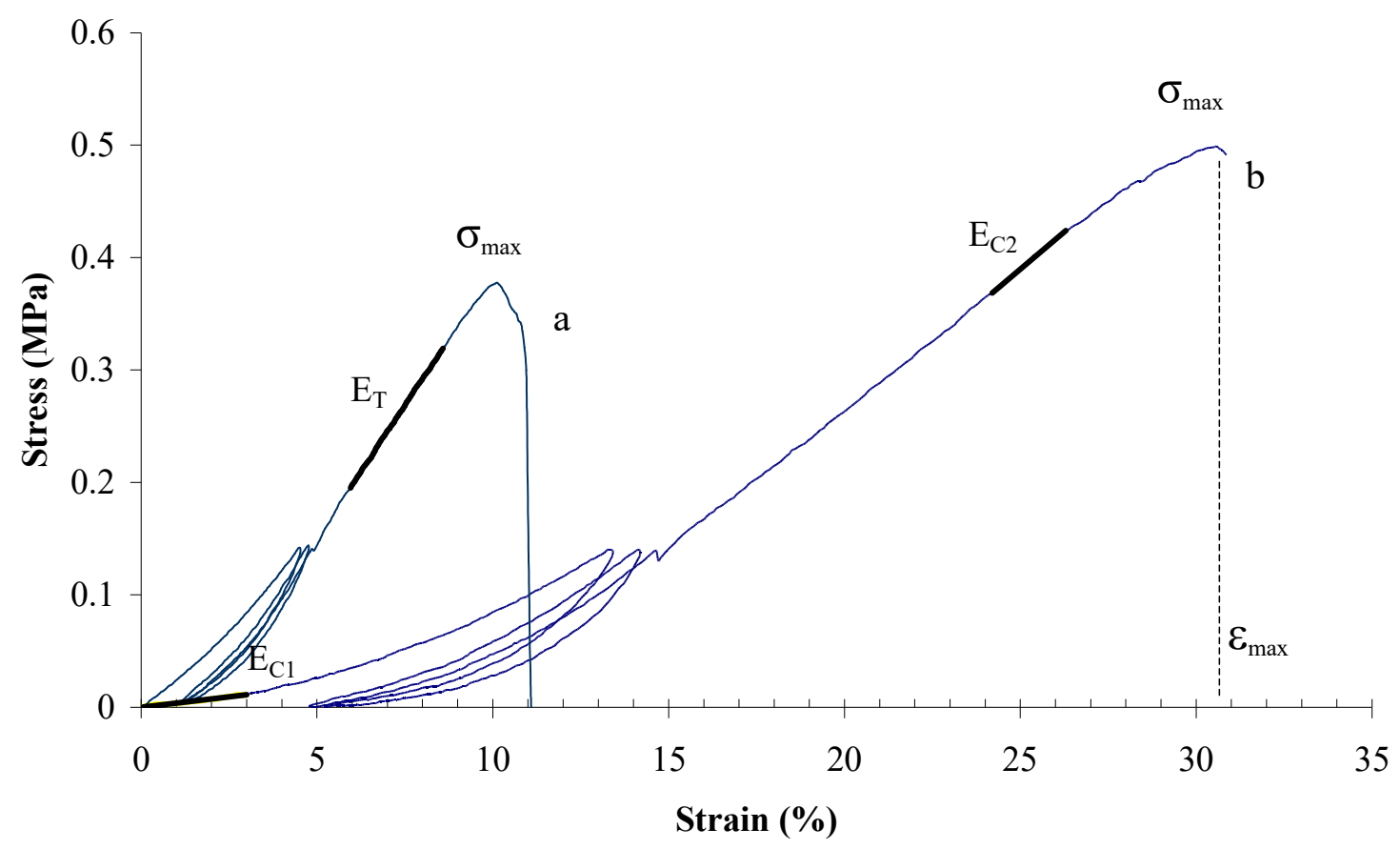

563

564Figure 4. Representative stress-strain curves of control apple tissue subjected to 565compression (a) and tension (b) loading. The bold lines on the curves represent the 566region from where the elasticity modulus and the associated images were extracted. 567EC1: elasticity modulus of samples under compression loading obtained at the 568beginning of the test; EC2: elasticity modulus of samples under compression tests, 569corresponding to $80 \%$ stress; ET: Elasticity modulus of samples under tensile tests; $570 ? \max$ : maximum stress; $「$ max: strain at maximum stress. 
Braeburn
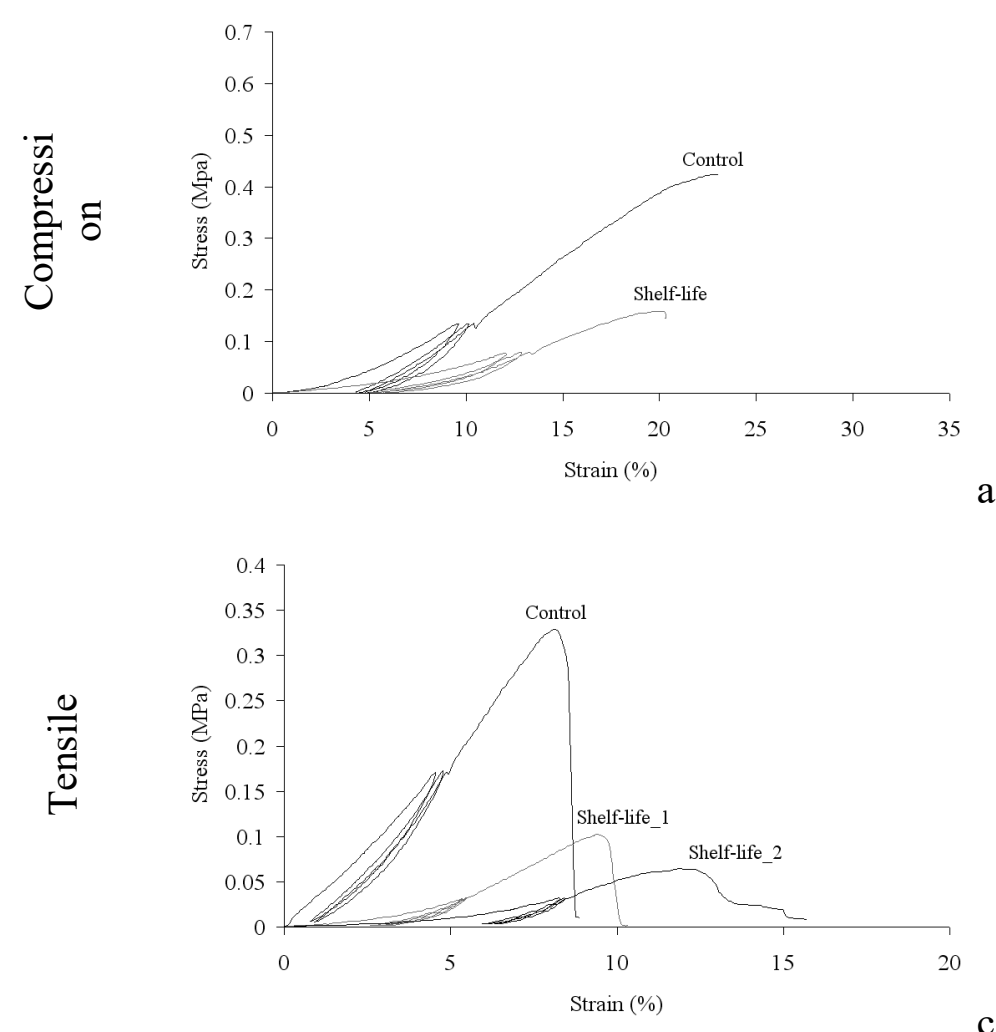
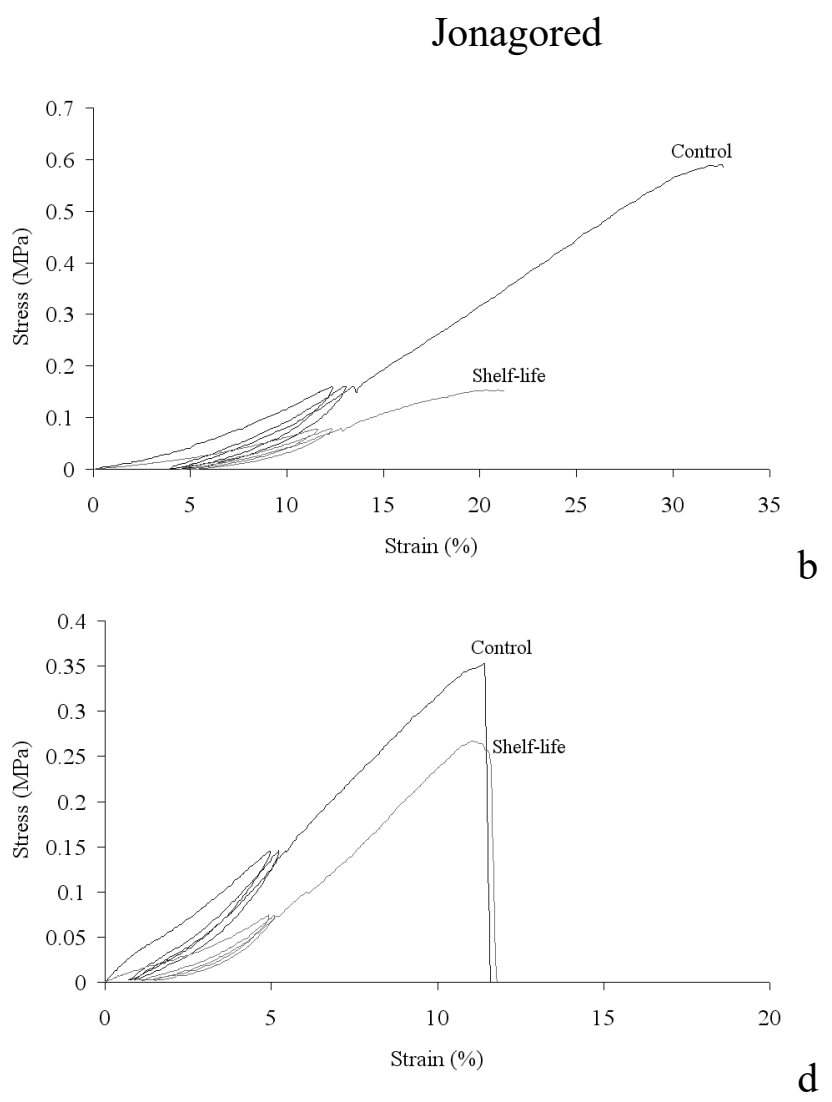

574

575Figure 5. Typical stress-strain curves for Braeburn and Jonagored apple tissue under different storage conditions (control and shelf-life) 576subjected to tensile and compression tests.

577 
